Marcin Sieńkowski

Wyższe Seminarium Duchowne Diecezji Ełckiej, Ełk

ORCID: 0000-0002-0679-5006

e-mail: sienkowskimarcin@interia.pl

\title{
Filozoficzne podstawy pokoju wewnątrz człowieka w ujęciu Tomasza z Akwinu i Immanuela Kanta
}

Bezpieczeństwo i pokój to tematy podejmowane dziś z dużo większą częstotliwością niż chociażby dwie dekady wcześniej. Jedną z przykładowych przyczyn tego zjawiska jest rosnąca liczba różnego rodzaju niebezpieczeństw łącznie z zagrożeniem utraty pokoju. Zarówno na temat pojedynczych incydentów osłabiających pokój czy zmniejszających bezpieczeństwo, jak również zmieniających się ogólnych postaw w świecie wypowiada się wielu ekspertów niejednokrotnie wykształconych na specjalnie zorganizowanych kierunkach studiów. Bynajmniej problematyka pokoju nie była ignorowana czy pomijana w minionych epokach. Podejmowało ją wielu światłych intelektualistów. Oprócz polityków czy socjologów zgłębiali ją także filozofowie. Przy czym należy pamiętać, że zagadnienie pokoju nie wyczerpuje się tylko $\mathrm{w}$ porządku zewnętrznym. Równie istotne jest podejmowanie refleksji dotyczącej pokoju w aspekcie wewnętrznym.

Analizy podjęte w niniejszym artykule zmierzają do ukazania filozoficznych podstaw pokoju wewnątrz człowieka w ujęciu św. Tomasza z Akwinu i Immanuela Kanta. Ponieważ reprezentują oni dwa odmienne typy filozofii, zestawienie ich poglądów może dostarczyć głębszego rozumienia poruszanego tematu. Poszukiwanie odpowiedzi na pytanie o filozoficzne podstawy tego rodzaju pokoju będzie przebiegać od wyjaśnienia tego, czym jest samo to pojęcie, poprzez nakreślenie sytuacji 
konfliktowych, aż do wskazania sposobów osiągnięcia i utrzymania pokoju w człowieku.

\section{Pojęcie pokoju wewnątrz człowieka}

Potrzebę zaprowadzenia pokoju Kant dostrzega przynajmniej w czterech płaszczyznach ludzkiej aktywności. Jak zauważa Heiner F. Klemme, filozof z Królewca mówi o pokoju między: 1) poszczególnymi szkołami filozoficznymi, 2) wydziałami uniwersyteckimi, 3) wewnątrz państwa oraz 4) między narodami ${ }^{56}$.

Lektura podstawowych dzieł Kanta pozwala dostrzec, że obok zagadnienia pokoju, który rodzi się między różnymi podmiotami, analizuje on również kwestię pokoju wewnętrznego jako pewnego stanu państwa ${ }^{57}$. Wprawdzie filozof z Królewca nie podejmuje tematu pokoju w człowieku wprost, jednakże na podstawie poszczególnych jego wypowiedzi możliwe jest zrekonstruowanie koncepcji pokoju wewnątrz człowieka. Najogólniej rzecz biorąc, pokój tego typu można porównać do spokoju ducha. Istotne znaczenie ma tu pewnego rodzaju zależność. Chodzi o to, że zaprowadzenie pokoju między ludźmi i narodami dokonuje się analogicznie do wewnętrznej przemiany ludzkiej natury ${ }^{58}$. Wobec tego oba aspekty pokoju są ze sobą powiązane i zależne do tego stopnia, że zrozumienie istoty pokoju zewnętrznego pociąga za sobą uchwycenie sensu pokoju zachodzącego we wnętrzu człowieka. Dlatego Kanta koncepcja pokoju dotycząca człowieka występuje przede wszystkim na gruncie filozofii praktycznej, która obejmuje sferę moralną kierowaną wolą człowieka ${ }^{59}$.

W tym miejscu wystarczy powiedzieć, że pokój wewnątrz człowieka w rozumieniu Kanta polega na uporządkowaniu motywów (pobudek),

56 Por. Heiner F. Klemme. "Przedmowa do wydania polskiego”. W: Immanuel Kant. O porzekadle: to może być stuszne w teorii, ale nic nie jest warte w praktyce. Do wiecznego pokoju. Projekt filozoficzny, przeł. Mirosław Żelazny (Toruń: Wydawnictwo COMER, 1995), LXXI. Temu ostatniemu została poświęcona rozprawa zatytułowana Do wiecznego pokoju. Zob. Immanuel Kant, „Do wiecznego pokoju. Projekt filozoficzny". W: Immanuel Kant. O porzekadle: to może być słuszne w teorii..., 47-96.

57 Por. Heiner F. Klemme, „Wstęp”. W: Kant, O porzekadle: to może być stuszne w teorii..., LIX.

58 To nic innego, jak chrześcijańska idea nowego człowieka (jego nowych narodzin). Por. Tomasz Kupś. „Religijny kontekst Kantowskiej idei „wiecznego pokoju". Dostęp 28.10.2020. http://www.repozytorium.uni.wroc.pl/Content/66122/05_Tomasz_Kups.pdf, 83; Jan Kalniuk. „Pokój”. W: Jan Paweł II - Encyklopedia Nauczania Społecznego. Red. A. Zwoliński. Radom: Polwen Polskie Wydawnictwo Encyklopedyczne, 2005, 366.

59 Por. Frederick Copleston. Historia filozofii. T. 6: Od Wolffa do Kanta, przeł. Jerzy Łoziński (Warszawa: Instytut Wydawniczy PAX, 2005), 188. 
które oddziałują na wolę. Jeżeli motywy te nie przeczą sobie czy też nie wchodzą ze sobą w konflikt, to w człowieku zachodzi stan nazywany pokojem (czy wręcz spokojem). W przeciwnym razie ma miejsce niepokój, czyli stan, który rodzi się w wyniku motywowania woli nieuporządkowanymi pobudkami. W tym sensie pokój wewnętrzny jest zharmonizowaniem motywów kierujących działaniami człowieka.

Podobnie jak Kant, św. Tomasz z Akwinu podkreśla, że pojęcie pokoju jest zagadnieniem wieloaspektowym. W jednym z podstawowych tekstów poświęconych tej kwestii wskazuje on, że pokój może dotyczyć relacji: 1) między narodami (państwami), 2) między poszczególnymi ludźmi (i społecznościami) oraz 3) w samym człowieku ${ }^{60}$. Zrozumienie natury i poznanie mechanizmów warunkujących pokój wewnątrz człowieka jest o tyle istotne, o ile te same zasady dotyczą rozumienia pokoju każdego innego typu. W tym aspekcie Tomasz z Akwinu zgadza się z Kantem. Dlatego należy zauważyć, że obaj filozofowie dostrzegają zależności, jakie zachodzą między różnymi wymiarami pokoju.

Wprawdzie zewnętrzny aspekt pokoju pozostaje poza obszarem rozważań podejmowanych w tym tekście, jednakże pewnego wyjaśnienia domaga się kwestia relacji między pokojem i zgodą. $Z$ reguły przyjmuje się, że pokój dotyczy przede wszystkim stosunków między ludźmi. Jednakże w Sumie teologicznej na określenie relacji między osobami lub społecznościami Tomasz z Akwinu używa terminu zgoda (concordia). Natomiast pojęcie pokoju (pax) rezerwuje głównie dla oznaczenia wewnętrznego stanu człowieka ${ }^{61}$.

Tomasz utrzymuje, że pokój wewnętrzny polega na zjednoczeniu pragnień (appetitus) ${ }^{62}$ człowieka, zaś pokój zewnętrzny dotyczy zharmonizowania jego pragnień z pragnieniami innych ludzi ${ }^{63}$. Innymi słowy, pokój w człowieku to zespolenie pragnień i dążeń. Ponieważ występują

${ }^{60}$ Por. STh 2-2, q. 29. Znamienne, że św. Tomasz z Akwinu analizuje pojęcie pokoju w ramach kwestii poświęconych miłości, a nie np. sprawiedliwości. Akwinata uważa, że pośrednio pokój jest wynikiem miłowania, a bezpośrednio radości. Por. Stanisław Kowalczyk. „Filozofia pokoju św. Tomasza z Akwinu”. Roczniki Nauk Społecznych 16-17 (1988-1989), z. 1: 69.

61 Por. STh 2-2, q. 29, a. 1, ad 2.

${ }^{62} \mathrm{Na}$ trudności związane $\mathrm{z}$ tłumaczeniem łacińskiego terminu appetitus wskazuje np. Stefan Swieżawski. Jego zdaniem, należy zdawać sobie sprawę z tego, że polskie odpowiedniki typu "pragnienie", "pożądanie”, ,chcenie” czy „dążenie” nie oddają pełnej treści przypisywanej pojęciu appetitus. Dlatego np. słowo "pożądanie” należy rozumieć szeroko jako sferę pragnieniowo-dążeniowa, którą przeciwstawia się dziedzinie poznawczej. Por. Stefan Swieżawski. „Wstęp do kwestii 80”. W: Tomasz z Akwinu. Traktat o człowieku. Summa teologii 1, 75-89, przeł. Stefan Swieżawski (Kęty: Wydawnictwo Antyk 2000), 343.

${ }_{63}$ Por. STh 2-2, q. 29, a. 3; Marek Aureliusz. Rozmyślania, przeł. Marian Reiter (Warszawa: PWN, 1984), 57; Seneka. „O życiu szczęśliwym”. W: Teksty filozoficzne. Red. M. Łojek (Warszawa: Instytut Wydawniczy PAX, 1987), 91. 
w nim dążenia różnego rodzaju, pokój jest stanem ich uporządkowania. Z chwilą osiągnięcia pokoju następuje uspokojenie i ustanie walki, która toczy się między pragnieniami. Aby ostatecznie zakończyć tę walkę, musi nastąpić obranie takiego celu, który polega na zjednoczeniu wszystkich dążeń. Takie ukierunkowanie problemu pokoju przenosi nas na płaszczyznę moralna, która polega na realizowaniu dobra stosownie do różnego rodzaju dążeń rodzących się w człowieku.

Filozoficzna refleksja Akwinaty dotycząca stosunku pokoju i zgody prowadzi do wniosku, że pokój i zgoda nie są tym samym. Twierdzi on wprawdzie, że pokój zawiera w sobie zgodę, ale zakresowo jest pojęciem szerszym (pokój zawiera w sobie zgodę, ale zgoda nie za każdym razem utożsamia się z pokojem). W potocznym rozumieniu zgoda dotyczy relacji między ludźmi. Jest ona takim stosunkiem między nimi, który wyraża się chceniem tego samego. W tym sensie zgoda to nic innego jak umowa, która polega na obraniu jednakowego celu. Przy czym zgoda nie musi dotyczyć całości pragnień, które żywią zgadzające się osoby. Wystarczy, że umowa obejmuje tylko niektóre z nich, a pozostałe pomija, chociażby z tego powodu, że nie są one przedmiotem tejże zgody ${ }^{64}$.

W odróżnieniu od zgody, która kładzie nacisk na zewnętrzne relacje między osobami, pokój dotyczy wewnętrznej sfery człowieka. Wprawdzie pokój obejmuje również ludzkie pragnienia, jednakże czyni to pod kątem ich wzajemnych relacji w ramach jednego człowieka. To znaczy, że pojęcie pokoju odnosi się do wnętrza człowieka, a pojęcie zgody dotyczy zewnętrznych stosunków między ludźmi ${ }^{65}$. Wobec tego pokój nie jest tym samym co zgoda. Tomasz zauważa, że zgoda może zachodzić nawet między ludźmi niegodziwymi, którzy np. wspólnie decydują się czynić coś złego.

Poza pragnieniami, których dotyczy zgoda mogą pojawić się też takie, których ona nie obejmuje. Wola i uczucia nie są uspokojone, dopóki jest coś, co wprawdzie jest chciane, lecz nie może być osiągnięte. Takiego zjednoczenia nie dokonuje zgoda, lecz pokój, który jest zespoleniem pragnień wewnątrz jednego człowieka ${ }^{66}$. Pokój w człowieku to wewnętrzny ład, porządek. Nie może się on zrodzić, gdy zachodzą

${ }^{64}$ Ponieważ na gruncie filozofii realistycznej przedmiotem chcenia może być tylko dobro, zgoda między ludźmi polega na dążeniu do tego samego dobra. A skoro dobro chciane aktualnie staje się celem, to zgoda oznacza obranie i podążanie do jednego celu przez pewną grupę osób. Por. STh 2-2, q. 29, a. 1. Zgodę (pokój) między ludźmi św. Augustyn nazywa porządną zgodnością serc. Porządna zgoda to zgoda na to, co odpowiada wszystkim stronom. Nie ma mowy o rzeczywistym pokoju, gdy ktoś zgadza się na niego pod przymusem np. zagrażającego zła.

65 Por. STh 2-2, q. 29, a. 1.

66 Por. STh 2-2, q. 29, a. 1. 
nieskoordynowane pragnienia wielu rzeczy ze sobą sprzecznych lub niemożliwych do osiągnięcia równocześnie ${ }^{67}$.

Tomasz z Akwinu przywołuje również określenie pokoju, które pochodzi od św. Augustyna. Mowa tu o „ciszy porządku"68. Polega ona na uspokojeniu w człowieku wszystkich ruchów dążeniowych. A ponieważ ład przejawia się ciszą, ukojeniem, spoczynkiem, czy wręcz spokojem, to określenie Augustyna zyskało aprobatę Akwinaty. Innymi słowy, "cisza porządku" to wolność od udręk pochodzących z konfliktów dążeniowych.

Jeśli natomiast chodzi o Kanta rozumienie koncepcji pokoju czy to zewnętrznego, czy w człowieku, to w pierwszej kolejności należy zauważyć, że pojęcie to przeciwstawia on idei konfliktu. Na tej podstawie Kant wyjaśnia, że pokój polega na wygaszeniu źródeł konfliktu ${ }^{69}$. Jak zażegnanie konfliktu stanowi warunek zaprowadzenia pokoju, tak utrata pokoju następuje w wyniku rodzącego się konfliktu. Wobec tego oba te pojęcia wykluczają się. Ponieważ konflikt może pojawić się również w sferze wewnętrznej, to pokój jest przede wszystkim wewnętrznym porządkiem moralnym. Posługując się językiem Kanta należy powiedzieć, że pokój zachodzi wtedy, gdy zostaje zachowany odpowiedni porządek maksym determinujących wolę człowieka. Dlatego zjawisko pokoju należy do problematyki rozumu praktycznego, a nie teoretycznego ${ }^{70}$.

Pokój w człowieku to wewnętrzny porządek moralny, którego urzeczywistnienie dokonuje się poprzez przemianę woli. Zachodzi ona wtedy, gdy wola kieruje się wyłącznie maksymami wypływającymi z prawa moralnego. Innymi słowy, jest to ustanie wewnętrznej walki dobra ze złem. Człowiek jako istota moralna i rozumna stale toczy tego typu walkę ze słabościami własnej natury ${ }^{71}$. Celem walki wewnętrznej jest więc pokój (spokój) w człowieku². Natomiast przeciwnikiem tej walki jest to, co niszczy człowieka w aspekcie moralnym, czyli złe skłonności (Neigungen). Ich przezwyciężenie stanowi gwarancję zaprowadzenia pokoju. W ten sposób pokój nie następuje w wyniku traktatu pokojowego,

${ }^{67}$ O kimś, kto jest niepokojony różnymi pragnieniami mówi się, że sam nie wie, czego chce.

68 Św. Augustyna nazywa ją „,tranquillitas ordinis”. Por. STh 2-2, q. 29, a. 1, ad 1.

${ }^{69}$ Por. Immanuel Kant. Krytyka czystego rozumu, przeł. Roman Ingarden (Kęty: Wydawnictwo Antyk, 2001), 561-562; Alicja Żywczok, „Spokój wewnętrzny - wyznacznik bezpieczeństwa zbiorowego", Colloquium Wydziału Nauk Humanistycznych i Społecznych 2012, nr 4: 172-173.

${ }^{70}$ Por. Immanuel Kant. Metafizyka moralności, przeł. Ewa Nowak (Warszawa: PWN, 2005), 205; Martin Bondeli. „Między Kantem i Heglem: rozum jako rzecznik pokoju", przeł. Ewa Nowak-Juchacz. Principia 37-38 (2004): 107-108.

${ }^{71}$ Por. Kupś. „Religijny kontekst Kantowskiej idei „wiecznego pokoju”, 77.

72 Por. Immanuel Kant. Religia w obrębie samego rozumu, tłum. Aleksander Bobko (Kraków: Homini, 2007), 150 (dalej: RSR). 
lecz na skutek opanowania źródła sporu, którym jest złe motywowanie woli $^{73}$. Zdaniem Kanta, człowiek posiada predyspozycje do ustawicznego postępu. Wyrażają się one poprzez rozwój moralny, polegający na wzroście szacunku do prawa moralnego ${ }^{74}$.

Warto $\mathrm{w}$ tym miejscu chociaż nadmienić, że kwestię pokoju zewnętrznego Kant określa formułą „wiecznego pokoju”. Na gruncie polityki pokój tego rodzaju jest dobrem najwyższym. Stanowi on ostateczny cel porządku prawnego, a na płaszczyźnie filozofii prawa - naczelną ideę ${ }^{75}$.

\section{Dwa rodzaje konfliktów}

Już samo doświadczenie codziennego życia pokazuje, że dążenia (pragnienia, chcenie) nawet pojedynczego człowieka mogą być ze sobą sprzeczne $^{76}$. Tym bardziej trudno o zgodę w zamiarach i pragnieniach większej liczny osób. Tego rodzaju rozbieżność pojawia się co najmniej na dwóch płaszczyznach. Jedna z nich dotyczy stosunku różnych władz pożądawczych człowieka. Chodzi o to, że pożądanie zmysłowe (uczucia) może kierować się do czegoś innego niż pożądanie intelektualne (wola). Tę rozbieżność potwierdza chociażby fakt, że uczucia niechętnie poddają się kierowaniu woli. Konflikt tego rodzaju zwykło się nazywać różnicą władz dążeniowych ${ }^{77}$.

Inna płaszczyzna niezgodności zarysowuje się na gruncie różnych przedmiotów, do których może się kierować jedna i ta sama władza pożądawcza. Z reguły konkretna władza pożądawcza zmierza do wielu różnych rzeczy. Kłopot jednak w tym, że niekiedy ich odmienność nie pozwala na posiadanie ich wszystkich równocześnie. Wtedy pojawia się walka dążeń ze względu na przedmiot ${ }^{78}$. Tak więc antagonizm rodzi się albo między poszczególnymi władzami pożądawczymi, albo między różnymi przedmiotami. Oba tego rodzaju konflikty nie są obce ani

${ }^{73}$ Por. Kupś. „Religijny kontekst Kantowskiej idei „,wiecznego pokoju”, 78.

74 Por. Mirosław Żelazny. „Kant Immanuel”. W: Powszechna encyklopedia filozofii. Red. A. Maryniarczyk. T. 5 (Lublin: Polskie Towarzystwo Tomasza z Akwinu, 2004), 469-474.

75 Por. Klemme, „Wstęp”, LV.

${ }^{76}$ Chodzi tu nie tyle o sprzeczność, co o przeciwieństwo, które jest typem przeciwstawności. Por. Mieczysław Albert Krąpiec. Metafizyka. Zarys teorii bytu (Lublin: RW KUL, 1984), 150-151.

77 Wola znajduje się pod wpływem dwojakiego rodzaju oddziaływania: 1) zmysłowych władz pożądawczych (uczucia) oraz 2) intelektu. Por. np. STh 1, q. 82, a. 3-4; STh 1-2, q. 9, a. 13.

78 "(...) serce człowieka nie jest uspokojone, jak długo, choć ma to czego chce, to jednak przy tym chce jeszcze czegoś innego, czego razem z poprzednim osiągnąć nie może". STh 2-2, q. 29, a. 1. 
Tomaszowi z Akwinu, ani Kantowi ${ }^{79}$. Zwróćmy uwagę na przyjęte przez nich koncepcje władz pożądawczych wraz z ich przedmiotami oraz na relacje, jakie zachodzą między nimi, aby następnie wskazać sposoby zażegnania powstających konfliktów.

Zarówno Tomasza, jak i Kanta koncepcja władz pożądawczych z jednej strony dotyczy porządku zmysłowego, a z drugiej umysłowego. Akwinaty koncepcja władz pożądawczych ściśle wiąże się z aktami (czynnościami), które z kolei są przyporządkowane odpowiednim przedmiotom. W myśl zasady, która głosi, że przedmiot decyduje o akcie, zaś akt przynależy do określonej władzy, racją wyodrębnienia poszczególnych władz jest ich przedmiot. Dlatego nie można mówić o władzy z pominięciem jej przedmiotu. Ponadto należy pamiętać, że w człowieku jest zapodmiotowionych tyle różnych władz, ile przedmiotów (formalnych) da się wyróżnićs ${ }^{80}$.

Na gruncie filozofii realistycznej przyjmuje się, że przedmiotem pożądania jest byt $w$ aspekcie dobra ${ }^{81}$. To znaczy, że dobro jest przedmiotem władzy chcenia. Jednakże dobro może być ujęte na dwa sposoby. Pierwszy z nich dotyczy dobra konkretnego, drugi zaś dobra w wymiarze ogólnym ${ }^{82}$. Na tej podstawie wyróżnia się władze zmysłowe (uczucia) oraz władzę umysłową w postaci woli. Rozróżnienie to dowodzi, że w człowieku wyodrębnia się wiele władz, a w związku z tym zachodzi duże prawdopodobieństwo pojawienia się konfliktów między nimi. Ryzyko sporu wzrasta również ze względu na liczbę przedmiotów władz pożądania. Dlatego może dochodzić do konfliktów zarówno na poziomie władz, jak i na poziomie ich przedmiotów.

Przechodząc do analizy kantowskiej koncepcji władz pożądawczych (Begehrungsvermögen) i ich przedmiotów należy pamiętać, że jest ona ściśle powiązana z praktycznym aspektem ludzkiej egzystencji. Dlatego podstawy pokoju w człowieku nie mogą zostać ukazane inaczej, jak tylko na gruncie moralności. Kant zaznacza, że praktyczny porządek postępowania nazywany moralnością wyraźnie różni się od teoretycznego

${ }^{79}$ W tym miejscu trzeba zaznaczyć, że określenia typu „władze pożądawcze”, czy "przedmioty władz” należą przede wszystkim do terminologii stosowanej przez Tomasza z Akwinu. Jeśli przyjmie się, że możliwe jest ich stosowanie również na gruncie filozofii Kanta, to tylko z takim zastrzeżeniem, że dotyczą one podobnych mechanizmów, które w ramach moralności wskazuje i omawia Kant.

${ }^{80}$ O specyfice określonej władzy decyduje jej przedmiot formalny. Zob. STh 1, q. 77 , a. 3 .

${ }^{81}$ Por. Tomasz z Akwinu. „Dysputy problemowe O dobru”. W: Tomasz z Akwinu. Dysputy problemowe O dobru, O pożądaniu dobra i o woli, tłum. Aleksander Białek (Lublin: Wydawnictwo KUL, 2010), q. 21, a. 1.

82 Por. Tomasz Stępień. Wprowadzenie do antropologii filozoficznej św. Tomasz z Akwinu (Warszawa: Warszawskie Towarzystwo Teologiczne, 2013), 105-106. 
porządku poznania ${ }^{83}$. Ten drugi jest domeną rozumu spekulatywnego. Natomiast w porządku praktycznym wiodącą rolę odgrywa rozum praktyczny oraz wola ${ }^{84}$. Zadaniem intelektu jest stosowanie kategorii w ramach możliwego doświadczenia. Z kolei o rozumie praktycznym Kant mówi, że urzeczywistnia swoje przedmioty ${ }^{85}$. Przedmioty tego rodzaju to przede wszystkim decyzje i czyny moralne.

Źródeł konfliktu wewnętrznego Kant poszukuje w naturze (strukturze) człowieka. Ludzką naturę pojmuje on jako zmysłową i rozumną zarazem, a co za tym idzie, człowieka postrzega jako istotę przynależącą do dwóch światów: zmysłowego i nadzmysłowego. W świecie zmysłowym obowiązują prawa przyrody oparte na konieczności, a światem intelektu rządzą prawa moralne ufundowane na wolności. Wedle praw przyrody istnieje zmysłowa natura człowieka, a wedle praw moralnych - natura intelektualna ${ }^{86}$. Rzecz w tym, że prawa obu rodzajów roszczą sobie pretensje do determinowania woli, czyli do oddziaływania na nią $w$ taki sposób, aby mieć wpływ na decyzje podejmowane przez człowieka. Rywalizacja obu tego rodzaju wymiarów może stanowić zarzewie konfliktu. Wtedy jest to spór na poziomie przedmiotów władzy pożądania, czyli motywów (Bestimmungsgrund, Motiv) skłaniających wolę do podejmowania decyzji ${ }^{87}$.

Podobnie jak każda władza człowieka, wola koresponduje z właściwym sobie przedmiotem. Zostało już powiedziane, że na gruncie filozofii realistycznej przedmiotem woli jest dobro. Natomiast w apriorycznej filozofii Kanta wolę powinno determinować tylko i wyłącznie prawo moralne $^{88}$. Można powiedzieć, że wszelkie działania woli powinny następować tylko w wyniku zaktualizowania jej przez zdolny do tego przedmiot. Kant twierdzi, że jedynie prawo moralne posiada zdolność determinowania woli ${ }^{89}$.

83 Por. Kant, Metafizyka moralności, 13.

${ }^{84}$ Por. Immanuel Kant. Krytyka praktycznego rozumu, przeł. Jerzy Gałecki (Warszawa: PWN, 2012), 147 (dalej: KPR).

85 Por. KPR, 148.

${ }^{86}$ Por. KPR, 73-74.

${ }^{87}$ Jeśli prawo moralne jest tym, co determinuje wolę do działania, to (używając terminologii św. Tomasza) jest ono przedmiotem woli. Wprawdzie Kant tłumaczy, że prawo moralne stanowi przede wszystkim motyw (pobudkę) działania woli, jednakże nie stoi to w sprzeczności z uznawaniem go również za jej przedmiot. Przy czym należy pamiętać, że oprócz tego prawa są jeszcze inne motywy skłaniające wolę.

88 Por. KPR, 178.

89 Por. KPR, 122; Marcin Sieńkowski. „Koncepcja woli a rozumienie wiary. Ujęcie realistyczne, aprioryczne i pozytywistyczne". Studia Ełckie 21 (2019), nr 3: 369-375. Osobną kwestią jest to, że w rzeczywistości czynią to również inne czynniki. Jednakże Kanta rozumienie moralności polega na tym, że zawiera ona zasady, które powinne być stosowane, niezależnie od tego, czy praktyka życia przestrzega, czy narusza owe zasady. 
Filozof z Królewca podkreśla, że moralnie dobre czyny istoty rozumnej to takie czyny, które są podyktowane prawem moralnym. Źródłem tego prawa jest sam podmiot działający. Człowiek sam z siebie tworzy tego rodzaju prawo i stosuje się do niego, jest więc i podmiotem, i przedmiotem prawa moralnego. Podobnie jak w poznaniu spekulatywnym, tak też na gruncie moralności ma zastosowanie zasada nazwana przez Kanta przewrotem kopernikańskim. Aktywność podmiotu wyraża się w stanowieniu prawa, a nie tylko biernym jego odczytaniu $\mathrm{z}$ istniejącej rzeczywistości, jak to ma miejsce chociażby w moralności realistycznej.

Wola, która pozwala kierować się tylko prawem moralnym jest wolą świętą. Pobudki innego rodzaju niż to prawo nie są w stanie zmusić woli świętej do działania. Zdolność woli do generowania i kierowania się tylko i wyłącznie prawem moralnym Kant nazywa autonomią woli. Jest to jedno z ważniejszych pojęć kantowskiej filozofii praktycznej. Autonomia woli to zdolność ustanawiania prawa i postępowania wedle jego zasad ${ }^{90}$.

W tym miejscu warto przypomnieć, że Kant skonstruował metodę stanowienia prawa moralnego. Wyraża ją formuła imperatywu kategorycznego. Zgodnie z nią prawo tworzą tylko takie maksymy, które nadają się na prawo powszechne ${ }^{91}$. Imperatyw ten stwierdza, że bezwzględnie i koniecznie należy postępować w określony sposób, który polega na tym, że postępowanie, a w zasadzie sama jego forma musi być powszechnie prawodawcza. Ona jest formalnym i naczelnym motywem determinującym wolę. Dzięki temu z powyższej formuły imperatywu kategorycznego dają się wyprowadzić wszystkie obowiązki ${ }^{92}$.

Wolę, która ulega pobudkom innym niż prawo moralne Kant nazywa wolą patologiczną ${ }^{93}$. W opozycji do autonomii woli pobudki tego rodzaju przyczyniają się do utrwalenia heteronomii woli ${ }^{94} \mathrm{Z}$ punktu widzenia moralności pojęcia autonomii i heteronomii woli wykluczają się. Ta ostania polega na tym, że wola ulega skłonnościom przeciwnym prawu moralnemu. Skłonności to nic innego, jak pobudki typu uczucia, przyjemności, doznania, które przeciwstawiają się prawu moralnemu ${ }^{95}$.

90 Por. KPR, s. 57-58.

91 „Postępuj tylko według takiej maksymy, dzięki której możesz zarazem chcieć, żeby stała się powszechnym prawem". Immanuel Kant. Uzasadnienie metafizyki moralności, przeł. Mścisław Wartenberg (Kęty: Wydawnictwo Marek Derewiecki, 2009), 38 (dalej: UMM); por. KPR, 53. „(...) nie powinienem nigdy inaczej postępować jak tylko tak, żebym mógł także chcieć, aby maksyma moja stała się powszechnym prawem". UMM, 19.

${ }_{92}$ Por. UMM, 39-41; Marek Blaszke, „Projekt wiecznego pokoju: de Saint-Pierre, Rousseau, Kant". ГOФIA. Pismo Filozofów Krajów Stowiańskich 13 (2013): 106.

93 Por. KPR, 32, 171.

${ }^{94}$ Por. KPR, 61; UMM, 49-50.

95 Por. UMM, 31, przypis 3. W innym miejscu Kant definiuje skłonność jako pragnienie zmysłowe wynikające z przyzwyczajenia. Natomiast samo pragnienie (appetitio) rozumie jako autodeterminowanie podmiotu dzięki przedstawieniu przyszłego skutku. Por. Immanuel Kant. Antropologia w ujęciu pragmatycznym, tłum. Paulina 
Celem, dla którego skłonności zmierzają do zdeprecjonowania prawa moralnego jest miłość własna ${ }^{96}$. Wypływa ona ze zmysłowego wymiaru natury człowieka. Wszystkie skłonności razem wzięte wiodą do szczęśliwości, czyli zadowolenia ze swego stanu ${ }^{97}$. Tak oto szczęśliwość jest celem zmysłowej natury człowieka, a przeciwstawiana jej cnotliwość, czyli postępowanie zgodne z prawem moralnym - stanowi cel natury intelektualnej. $\mathrm{W}$ ten sposób $\mathrm{w}$ jednym człowieku spotykają się dwie płaszczyzny jednej natury ludzkiej ${ }^{98}$. Każdej z nich Kant przypisał osobną władzę pożądania. Natura zmysłowa oddziaływuje na niższa, a natura intelektualna na wyższą władzę pożądania ${ }^{99}$. Problem jednak w tym, w jaki sposób pogodzić je ze sobą? Jak zaprowadzić pokój (porządek) między nimi?

\section{Rozwiq̨zanie konfliktów}

Rozpoznanie zaistniałego konfliktu dotyczącego dążeń człowieka stanowi punkt wyjścia w poszukiwaniu rozwiązania, które polega na zaprowadzeniu pokoju. Jeśli z jednej strony konflikt może dotyczyć władz, a z drugiej ich przedmiotów, to zabieganie o pokój dokonuje się stosownie do rodzaju konfliktu.

Zdaniem Tomasza z Akwinu, podążanie do jakiegoś dobra-celu wiąże się z zarówno z zamiarem jego osiągnięcia (posiadania), co łączy się z doborem odpowiednich środków, jak również z usunięciem przeszkód, które pojawiają się na drodze do celu ${ }^{100}$. Samo zmierzanie do dobra dokonuje się z tego powodu, że człowiek jako byt potencjalny nie wystarcza sam sobie, a dzięki osiągniętemu dobru uzupełnia swoje braki (aktualizuje się) $)^{101}$.

Tomasz wyjaśnia, że tym, co usuwa przeszkody na drodze do pokoju jest sprawiedliwość. Wtedy sprawiedliwość jest wprawdzie sprawcą pokoju, ale tylko pośrednio. Natomiast bezpośrednią przyczyną

Sosnowska, Ewa Drzazgowska (Warszawa: IFiS PAN, 2005), 189; Heiner F. Klemme. Oblicza wolności. Studia z praktycznej filozofii Kanta i jej historii, tłum. Dariusz Pakalski (Toruń: Wydawnictwo Naukowe UMK, 2013), 238.

96 Por. KPR, 121.

97 Por. KPR, 39-41.

98 Por. James M. Byrne. Religion and the Enlightenment: From Descartes to Kant (Kentucky: Westminster John Knox Press, 1996), 220.

99 Por. KPR, 39-41; Gilles Deleuze. Filozofia krytyczna Kanta. Doktryna władz, przeł. Bogdan Banasiak (Gdańsk: Wydawnictwo: słowo/obraz terytoria, 1999), 14-21.

100 Tomasz twierdzi, że pokój jest właśnie tym, co usuwa przeszkody. Jego istota polega na tym, że zamierzone dobro osiąga się spokojnie i bez przeszkód. Por. STh 2-2, q. 29, a. 2.

101 Por. Mieczysław Albert Krąpiec. Ja - człowiek (Lublin: Wydawnictwo KUL, 2005), 301. 
sprawiającą pokój jest miłość (charitas) $)^{102}$. Świadczy to przede wszystkim o tym, że miłość jest największą siłą jednoczącą.

Zdaniem Akwinaty, pokój między władzami następuje wtedy, gdy pierwszeństwo zyskuje władza doskonalsza. Pośród pożądawczych władz zmysłowych i umysłowych najdoskonalszą jest wola. W związku z tym władze zmysłowe w postaci uczuć muszą zostać podporządkowane woli. $\mathrm{Z}$ kolei na poziomie przedmiotów niezbędne jest rozpoznanie słusznego dobra. $\mathrm{W}$ tym celu przydatna jest umiejętność rozróżniania dóbr przyjemnościowych, użytecznych i godziwych ${ }^{103}$.

Wybór doskonalszego dobra umożliwiają różnego rodzaju usprawnienia władz umysłowych człowieka w postaci cnót. Z filozoficznego punktu widzenia problem cnót $\mathrm{w}$ życiu moralnym jest bardzo istotny. Jeśli podstawą dobra i zła moralnego jest decyzja, to chodzi o takie ukształtowanie człowieka, które ułatwia mu rozpoznanie realnego dobra, a następnie dostarcza sił do podążania w jego kierunku. Tego typu rozwój następuje dzięki usprawnieniu władz poznawczych i wolitywnych. Usprawnienia dodatnie, czyli cnoty są tym, co ułatwia człowiekowi rozpoznanie i czynienie dobra, a zarazem unikanie zła ${ }^{104}$.

Skoro poprzez decyzję człowiek zmierza do określonego dobra, to zadaniem cnót jest ułatwienie podjęcia decyzji. A ponieważ decyzja zapada na podstawie dialogu intelektu i woli, to usprawnienie tych dwóch władz stanowi o rozwoju człowieka, o stawaniu się dojrzalszym człowiekiem. Kształtowanie obu tych władz jest niezbędne również z tego powodu, że rozum nie zawsze poznaje prawdę, a wola nie za każdym razem wybiera słuszne dobro. Stąd konieczna jest refleksja przed podjęciem decyzji ${ }^{105}$.

Rozum i wola muszą być opanowane i ukształtowane, aby osiągnęły pełnię swojej doskonałości (optimum potentiae) z uwagi na dobro człowieka. Usprawnienie umysłowych władz człowieka pozwala na

102 Por. STh 2-2, q. 29, a. 3, ad 3; STh 2-2, q. 29, a. 4; Kowalczyk. Filozofia pokoju..., 71. Pokój zbudowany na krzywdzie, na łamaniu praw cudzych, jest pokojem pozornym, nietrwałym.

103 Por. Karol Wojtyła. Elementarz etyczny (Lublin: Towarzystwo Naukowe KUL, 1999), 62-64; Artur Andrzejuk. Prawda o dobru. Problem filozoficznych podstaw etyki tomistycznej (Warszawa: Wydawnictwo Uniwersytetu Kardynała Stefana Wyszyńskiego, 2000), 25; Marcin Sieńkowski, „Koncepcja dobra najwyższego w ujęciu Tomasza z Akwinu i Immanuela Kanta". Nurt SVD 145 (2019), nr 1: 236-252.

${ }_{104}$ Celem wszelkich cnót jest przede wszystkim rozwój i ochrona dobra ludzkiego. Por. Piotr Jaroszyński. Etyka. Dramat życia moralnego (Warszawa: Wydawnictwo Sióstr Loretanek, 2002), 46. Na temat procesu odwrotnego do doskonalenia człowieka zob. np. Piotr Stanisław Mazur. „Formowanie i deformacja obrazu osoby ludzkiej zagrożenia cywilizacyjne". Człowiek w Kulturze 28 (2018): 137-149.

${ }_{105}$ Człowiek nie może żyć dowolnie, jego zadaniem jest prowadzić życie ludzkie, czyli oparte na rozumie i woli. Życie tego rodzaju jest fundamentalnym dobrem człowieka. Por. Jaroszyński, Etyka..., 48. 
samodzielne postępowanie zgodnie z prawem moralnym. Sprawności tego typu umożliwiają względnie szybkie i łatwe, a nawet przyjemnie pójście za słusznym dobrem. Cnoty, które usprawniają postępowanie moralne to cnoty etyczne. Przyczyniają się one do troski o dobro ludzkie.

Roztropność usprawnia rozum, aby rozpoznał dobro. Umiarkowanie polega na umiejętności panowania nad uczuciami przyjemnymi i przykrymi, które mogą odwodzić od obiektywnego dobra. W opanowaniu uczuć strachu i bólu, które powodują obranie błędnego kierunku pomaga cnota męstwa. Z kolei sprawiedliwość przyczynia się do troski o własne dobro, jak również o dobro innych, którzy mają takie same prawa. Polega ona na oddawaniu tego, co komu się słusznie należy ${ }^{106}$.

Nabywanie tego typu usprawnień pozwala rozwiązać niejeden konflikt moralny, a dzięki temu zaprowadzić pokój wewnątrz człowieka. Zdaniem Tomasza z Akwinu, cnoty moralne usprawniają wolę, aby nie rezygnowała z decyzji o słusznym dobru. Rozum z kolei zyskuje zdolność rozpoznawania rzeczywistego dobra i odrzucania dobra pozornego.

Również u Kanta można wyróżnić dwa sposoby dążenia do pokoju w człowieku stosownie do dwóch rodzajów konfliktu (między władzami i ich przedmiotami, a w zasadzie motywami, pobudkami). Wobec dwojakiego typu zasad kierujących istotą rozumna, czyli praw moralnych konstytuujących świat intelektualny oraz praw przyrody obowiązujących w świecie zjawisk, wewnętrzny porządek moralny w postaci harmonii może zapanować tylko wtedy, gdy zostanie ustalona odpowiednia relacja między nimi. Zdaniem Kanta, polega ona na tym, że pierwszeństwo przypisuje się prawu moralnemu jako zasadzie bezwzględnej, natomiast prawa natury zmysłowej zostają podporządkowane prawom moralnym. Przestrzeganie tego porządku gasi wszelkie konflikty moralne i zaprowadza wewnętrzny porządek.

W tym miejscu warto zaznaczyć, że w celu ukrócenia wpływów, o jakie zabiegają motywy przeciwne prawu moralnemu, postępowaniu wedle praw praktycznych Kant nadał formę nakazu (imperatywu, powinności). Jego zadaniem jest uchronienie woli od pobudek patologicznych ${ }^{107}$. Dlatego działania, które są podyktowane prawem moralnym Kant nazywa działaniami z obowiązku ${ }^{108}$. Obowiązek to nic innego jak konieczność określonego postępowania, od którego nie wolno się

106 Por. Tomasz z Akwinu. Summa contra gentiles, przeł. Zofia Włodek, Włodzimierz Zega. T. 2 (Poznań: W drodze, 2007), III, 38; Artur Andrzejuk. Człowiek $i$ dobro (Warszawa: Oficyna Wydawnicza Navo, 2002), 45-75.

107 Por. KPR, 32, 171.

108 Por. UMM, 17. 
uchylić. Konieczność ta jest podyktowana poszanowaniem prawa moralnego ${ }^{109}$.

Rozważania Kanta dotyczące pokoju w człowieku w dużym stopniu wiążą się z rozumieniem dobra i zła moralnego. Najprościej mówiąc, zło moralne polega na subiektywnym odstępstwie maksymy od prawa moralnego ${ }^{110}$. Natomiast dobro moralne to nic innego jak postępowanie wedle zasad moralnych. Wobec tego Kant twierdzi, że człowieka nie nazywa się złym moralnie z powodu popełnianych przez niego złych czynów. Przyczyny stania się złym człowiekiem leżą w złych maksymach, które wpływają na jego decyzje. Mówienie o człowieku, że z natury jest dobry lub zły moralnie, oznacza tkwiącą $\mathrm{w}$ nim podstawę do przyjmowania dobrych lub złych maksym. Zgodnie z tym można powiedzieć, że w moralnie dobrym człowieku panuje spokój wynikający z zachowania zasady autonomii woli, natomiast człowiekiem moralnie złym rządzi przeciwieństwo tego stanu ${ }^{111}$.

Kant wyjaśnia, że różnica między moralnie dobrym a złym człowiekiem leży nie $\mathrm{w}$ różnicy motywów kierujących wolą lecz $\mathrm{w}$ ich wzajemnym podporządkowaniu, czyli w tym, którą z maksym czyni się warunkiem drugiej. Zatem moralnie dobry człowiek to taki, który daje pierwszeństwo maksymom opartym na prawie moralnym i podporządkowuje im maksymy przyjęte na podstawie pobudek zmysłowych, tworzących zasadę miłości własnej (szczęśliwości). W przeciwnym razie jego usposobienie kwalifikuje się jako moralnie złe ${ }^{112}$. Prawo miłości własnej nie może istnieć na równi z prawem moralnym, lecz musi być mu podporządkowane jako swemu warunkowi, aby w człowieku mogło zapanować uporządkowanie władz pożądawczych.

Jeśli chodzi o kształtowanie człowieka, to Kant podkreśla, że rozwój moralny nie polega na odzyskaniu pobudki do dobra, lecz na odnowieniu prawa moralnego jako naczelnej podstawy wszystkich maksym. Zdolność przestrzegania obowiązku to nic innego jak cnota. Stać się człowiekiem moralnie dobrym (cnotliwym), to uczynić rozpoznany obowiązek wystarczająca pobudką swej woli ${ }^{113}$.

W ten sposób staje się zrozumiałe, że moralne kształtowanie człowieka polega na zmianie sposobu myślenia, a nie na poprawie obyczajów. Służy temu wzbudzenie szacunku do postępowania wedle prawa moralnego ${ }^{114}$. Ponieważ jednak skłonność do przyjmowania maksym

109 Por. UMM, 18; KPR, 135.

110 Por. RSR, 53-54.

111 Por. RSR, 155-165 (opis Kościoła triumfującego); UMM, 11-12.

112 Por. RSR, 61-62, 69, 105.

113 Por. RSR, 75-76.

114, „(..) w bezwarunkowym szacunku dla prawa, jako dla najwyższego warunku wszystkich przyjmowanych maksym, przywrócony zostaje pierwotny moralny 
sprzecznych z prawem moralnym jest nie do przezwyciężenia, potrzeba stałego sprzeciwu wobec ich oddziaływania. Dlatego proces przechodzenia od złego do dobrego postępowania moralnego rozciąga się w nieskończoność ${ }^{115}$.

\section{Podsumowanie}

Treści zestawione $\mathrm{w}$ niniejszym artykule zmierzały do ukazania filozoficznych podstaw pokoju wewnątrz człowieka w ujęciu Tomasza z Akwinu i Immanuela Kanta. Nawet jeśli reprezentują oni dwa różne nurty filozoficzne, to $\mathrm{w}$ pewnym stopniu ich poglądy w omawianej tu kwestii są ze sobą zbieżne. Już samo pojęcie pokoju w człowieku zdaje się być rozumiane $\mathrm{w}$ tym samym duchu jako uporządkowanie pragnień, których problematyka podejmowana jest na gruncie moralności.

Omówienie dwóch rodzajów konfliktów, a następnie sposobów ich zażegnania pozwala wnosić, że filozoficzne podstawy pokoju wewnątrz człowieka tkwią w moralnym wymiarze jego struktury. Zasadniczą rolę odgrywa w niej koncepcja władz pożądawczych oraz koncepcja ich przedmiotów. Obaj filozofowie wyróżniają wyższą władzę pożądawczą w postaci woli, która może być skonfliktowana z władzami niższymi (zmysłowymi). Na tym poziomie pokój zachodzi wtedy, gdy woli podlegają władze niższego rzędu (np. uczucia, skłonności).

W przypadku konfliktu na poziomie przedmiotów (motywów) władz pożądawczych należy podkreślić, że obaj filozofowie przypisują woli inne przedmioty. Tomasz odnosi wolę do dobra, a Kant do prawa moralnego. Konflikt na tym poziomie może być rozwiązany wtedy, gdy wola nie pozwala się kierować przedmiotem niższego rzędu. Na gruncie filozofii realistycznej najistotniejszą rolę odgrywa dobro, które nie jest podporządkowane innemu dobru. $\mathrm{Z}$ kolei w ramach filozofii apriorycznej prawo moralne nie może być zastąpione skłonnościami (prawami zmysłowymi). W przeciwnym razie następuje zachwianie, a nawet utrata wewnętrznego porządku w człowieku.

\section{Bibliografia}

Andrzejuk Artur. 2002. Człowiek i dobro. Warszawa: Oficyna Wydawnicza Navo.

porządek pomiędzy pobudkami, a wraz z tym predyspozycja do dobra w ludzkim sercu w całej czystości". RSR, 79.

115 Por. RSR, 80; Immanuel Kant. Spór fakultetów, tłum. Mirosław Żelazny (Toruń: Rolewski, 2003), rozdział II. 
Andrzejuk Artur. 2000. Prawda o dobru. Problem filozoficznych podstaw etyki tomistyczne. Warszawa: Wydawnictwo Uniwersytetu Kardynała Stefana Wyszyńskiego.

Aureliusz Marek. 1984. Rozmyślania, przeł. Marian Reiter, Warszawa: PWN. Blaszke Marek. 2013. „Projekt wiecznego pokoju: de Saint-Pierre, Rousseau, Kant". इОФIA. Pismo Filozofów Krajów Słowiańskich 13: 93-108.

Bondeli Martin. 2004. „Między Kantem i Heglem: rozum jako rzecznik pokoju", przeł. Ewa Nowak-Juchacz. Principia 37-38: 105-123.

Byrne James M. 1996. Religion and the Enlightenment: From Descartes to Kant. Kentucky: Westminster John Knox Press.

Copleston Frederick. 2005. Historia filozofii. T. 6: Od Wolffa do Kanta, przeł. Jerzy Łoziński. Warszawa: Instytut Wydawniczy PAX.

Deleuze Gilles. 1999. Filozofia krytyczna Kanta. Doktryna wtadz, przeł. Bogdan Banasiak. Gdańsk: Wydawnictwo: słowo/obraz terytoria.

Jaroszyński Piotr. 2002. Etyka. Dramat życia moralnego. Warszawa: Wydawnictwo Sióstr Loretanek.

Kalniuk Jan. 2005. „Pokój”. W: Jan Paweł II - Encyklopedia Nauczania Społecznego. Red. A. Zwoliński. Radom: Polwen Polskie Wydawnictwo Encyklopedyczne, 365-367.

Kant Immanuel. 2005. Antropologia w ujęciu pragmatycznym, tłum. Paulina Sosnowska. Ewa Drzazgowska, Warszawa: IFiS PAN.

Kant Immanuel. 1995. „Do wiecznego pokoju. Projekt filozoficzny”. W: Immanuel Kant. O porzekadle: to może być stuszne w teorii, ale nic nie jest warte w praktyce. Do wiecznego pokoju. Projekt filozoficzny, przeł. Mirosław Żelazny. Torun: Wydawnictwo COMER, 47-96.

Kant Immanuel. 2001. Krytyka czystego rozumu, przeł. Roman Ingarden. Kęty: Wydawnictwo Antyk.

Kant Immanuel. 2012. Krytyka praktycznego rozumu, przeł. Jerzy Gałecki. Warszawa: PWN.

Kant Immanuel. 2005. Metafizyka moralności, przeł. Ewa Nowak. Warszawa: PWN.

Kant Immanuel. 1995. „O porzekadle: to może być słuszne w teorii, ale nic nie jest warte w praktyce". W: Immanuel Kant. O porzekadle: to może być stuszne w teorii, ale nic nie jest warte w praktyce. Do wiecznego pokoju. Projekt filozoficzny, przeł. Mirosław Żelazny. Toruń: Wydawnictwo COMER, $1-45$.

Kant Immanuel. 2007. Religia w obrębie samego rozumu, tłum. Aleksander Bobko. Kraków: Homini.

Kant Immanuel. 2003. Spór fakultetów, tłum. Mirosław Żelazny. Toruń: Rolewski.

Kant Immanuel. 2009. Uzasadnienie metafizyki moralności, przeł. Mścisław Wartenberg. Kęty: Wydawnictwo Marek Derewiecki.

Klemme Heiner F. 2013. Oblicza wolności. Studia z praktycznej filozofii Kanta i jej historii, tłum. Dariusz Pakalski. Toruń: Wydawnictwo Naukowe UMK.

Klemme Heiner F. 1995. „Przedmowa do wydania polskiego”. W: Immanuel Kant. O porzekadle: to może być stuszne w teorii, ale nic nie jest warte w prak- 
tyce. Do wiecznego pokoju. Projekt filozoficzny, przeł. Mirosław Żelazny. Toruń: Wydawnictwo COMER, VII-XXVIII.

Klemme Heiner F. 1995. „Wstęp”. W: Immanuel Kant. O porzekadle: to może być stuszne w teorii, ale nic nie jest warte w praktyce. Do wiecznego pokoju. Projekt filozoficzny, przeł. Mirosław Żelazny. Toruń: Wydawnictwo COMER, XXIX-LXX.

Kowalczyk Stanisław. 1988-1989. „Filozofia pokoju św. Tomasza z Akwinu". Roczniki Nauk Społecznych 16-17, z. 1: 69-90.

Krąpiec Mieczysław Albert. 2005. Ja - człowiek. Lublin: Wydawnictwo KUL.

Krąiec Mieczysław Albert. 1984. Metafizyka. Zarys teorii bytu. Lublin: RW KUL.

Kupś Tomasz. „Religijny kontekst Kantowskiej idei „wiecznego pokoju". Dostęp: 28.10.2020. http://www.repozytorium.uni.wroc.pl/Content/66122/05_Tomasz_Kups.pdf

Mazur Piotr Stanisław. 2018. „Formowanie i deformacja obrazu osoby ludzkiej - zagrożenia cywilizacyjne”. Człowiek w Kulturze 28: 137-149.

Seneka. 1987. „O życiu szczęśliwym”. W: Teksty filozoficzne, tłum. Martin Reiter. Red. M. Łojek. Warszawa: Instytut Wydawniczy PAX.

Sieńkowski Marcin. 2019. „Koncepcja dobra najwyższego w ujęciu Tomasza z Akwinu i Immanuela Kanta”. Nurt SVD 145, nr 1: 236-252.

Sieńkowski Marcin. 2019. „Koncepcja woli a rozumienie wiary. Ujęcie realistyczne, aprioryczne i pozytywistyczne". Studia Ełckie 21, nr 3: 363-384.

Stępień Tomasz. 2013. Wprowadzenie do antropologii filozoficznej św. Tomasz z Akwinu. Warszawa: Warszawskie Towarzystwo Teologiczne.

Swieżawski Stefan. 2000. „Wstęp do kwestii 80”. W: Tomasz z Akwinu. Traktat o człowieku. Summa teologii 1, 75-89, przeł. Stefan Swieżawski. Kęty: Wydawnictwo Antyk, 343-352.

Tomasz z Akwinu. 2010. „Dysputy problemowe O dobru”. W: Tomasz z Akwinu. Dysputy problemowe $O$ dobru, O pożądaniu dobra i o woli, tłum. Aleksander Białek, Lublin: Wydawnictwo KUL.

Tomasz z Akwinu. 1961-1986. Suma teologiczna. Red. S. Bełch. T. 1-34. London: Veritas.

Tomasz z Akwinu. 2007. Summa contra gentiles, przeł. Zofia Włodek, Włodzimierz Zega. T. 2. Poznań: W drodze.

Wojtyła Karol. 1999. Elementarz etyczny. Lublin: Towarzystwo Naukowe KUL.

Żelazny Mirosław. 2004. „Kant Immanuel”. W: Powszechna encyklopedia filozofii. Red. A. Maryniarczyk. T. 5: 469-474. Lublin: Polskie Towarzystwo Tomasza z Akwinu.

Żywczok Alicja. 2012. „Spokój wewnętrzny - wyznacznik bezpieczeństwa zbiorowego". Colloquium Wydziału Nauk Humanistycznych i Społecznych 4: 171-188. 


\section{Streszczenie}

Celem artykułu jest próba ukazania filozoficznych podstaw pokoju wewnątrz człowieka w ujęciu Tomasza z Akwinu i Immanuela Kanta. Znaczna jego część dotyczy omówienia konfliktów, które mogą zachodzić między różnymi władzami pożądawczymi oraz między przedmiotami tychże władz. Następnie ma miejsce analiza sposobów rozwiązania możliwych konfliktów. Obaj filozofowie wskazuja, że na poziomie władz konflikt może zostać rozwiązany dzięki właściwemu ich uporządkowaniu (władza wyższa kieruje władzą niższą). Konflikt na poziomie przedmiotów (ewentualnie motywów) władz zażegnuje się poprzez wybór dobra wyżej stojącego w hierarchii (ewentualnie kierowanie się wyłącznie prawem moralnym). Na tej podstawie wnioskuje się, że filozoficzne podstawy pokoju wewnątrz człowieka tkwią przede wszystkim w moralnym wymiarze jego natury.

Słowa kluczowe: filozofia, pokój, pokój wewnątrz człowieka, zgoda, konflikt, uporządkowanie pragnień, Tomasz z Akwinu, Immanuel Kant.

\section{Philosophical Foundations of Peace within Man According to Thomas Aquinas and Immanuel Kant}

\section{Summary}

The aim of the article is to present the philosophical foundations of peace within man as defined by Thomas Aquinas and Immanuel Kant. Much of it deals with the discussion of conflicts that may arise between various lusting powers and between the subjects of these powers. Then there is an analysis of ways to resolve possible conflicts. Both philosophers point out that the conflict can be resolved on the level of powers thanks to their proper ordering (the higher power directs the lower power). Conflict on the level of objects (or motives - Kant) of the powers is resolved by choosing the good higher in the hierarchy (or being guided solely by the moral law - Kant). On this basis, it is concluded that the philosophical foundations of peace within man lie primarily in the moral dimension of his nature.

Keywords: philosophy, peace, peace within man, harmony, conflict, ordering desires, Thomas Aquinas, Immanuel Kant. 